\title{
Sri Lanka's Tea Economy: Issues and Strategies
}

\author{
Mohamed Ismail Mujahid Hilal ${ }^{1}$ \\ ${ }^{1}$ Faculty of Management \& Commerce, South Eastern University of Sri Lanka, Oluvil, Sri Lanka \\ Correspondence: Mohamed Ismail Mujahid Hilal, Faculty of Management \& Commerce, South Eastern \\ University of Sri Lanka, Oluvil, Sri Lanka. E-mail: mujahidh@seu.ac.lk
}

Received: November 12, 2019

Accepted: November 28, 2019

Online Published: December 3, 2019

doi:10.5539/jpl.v13n1p1

URL: https://doi.org/10.5539/jpl.v13n1p1

\begin{abstract}
While the competitiveness of the Sri Lanka's tea is declining in the global market, it is very important for Sri Lankan tea to evidently identify the reasons for declining competitiveness and how Sri Lanka can face this challenge fulfilling the demand of global market. The Sri Lankan tea industry has lost its market leadership position in the global market. With declining production, increasing cost of production, low farm productivity and price competition in the international market, Sri Lankan tea industry has lost its competitive advantage. Secondary data and primary data have been used for this study. 53 interviews have been conducted for this study in Sri Lanka and in India. Despite the fact that Sri Lanka is one of the major producers of tea, the local tea industry does not earn enough to be viable. Global consumers are paying more than ten times the price received by the Sri Lankan producers. The value addition is taking place in the consuming countries and the economic benefits of higher price for value added tea products go to the consuming countries. In this context the viability of the Sri Lankan tea industry makes it imperative to adopt production of value-added tea products, promoting local brands in the global market and marketing the products in the international market. The government should also provide further supports to this tea industry to be uplifted in the country.
\end{abstract}

Keyword: Sri Lanka, tea economy, competitiveness, tea export

\section{Introduction}

The Sri Lankan tea industry, with a history of around one and a half centuries, is now facing global challenges. For more than a century, Sri Lanka was the largest exporter of tea in the world and Sri Lankan tea continues to maintain a differentiated image in the country markets where the Ceylon tea is being consumed. Although Sri Lanka is one of the major tea producing countries in the world, unlike other major producers Sri Lanka major portion of the tea production approximately 90 percent being sent to the world markets. Sri Lankan tea economy contributes to more than one million employment in the country directly and indirectly. The tea industry also helps the Sri Lankan economy earn about 15 percent of foreign exchange earnings. Any change in the fortunes of the industry can seriously affect the health of the Sri Lankan economy.

Some studies have been conducted on different aspects of the tea industry in Sri Lanka. Most of the studies addressed particular issues relevant to the tea industry such as commodity exports, increasing cost of production, declining farm productivity, small holders' problems and decreasing competitive advantage. A few of these studies had addressed selected issues pertaining to the marketing of Sri Lankan tea. However, there are no detailed studies on the prospects for international marketing of value-added tea products from Sri Lanka. Hence, the study is very important for generating ideas for the development of the tea industry in Sri Lanka.

Global tea production has been increasing and global tea consumption has also been growing. There has been a steady growth in global tea imports as well. Still Sri Lankan tea exports have been declining. Tea consumption in the world market is changing in favour of tea products such as teabags, instant tea, green tea and organic tea, replacing bulk tea. For instance, 75 per cent the market in the Middle East and Pakistan are for packet tea and over two thirds of the western and Northern American markets are for tea bags and instant tea. Thus, markets are shifting away from bulk tea towards value added tea products. Sri Lankan tea industry has failed to explore the needs of consumers in the international market and it is just exporting tea as commodity.

Due to the changes in the consumption pattern, Sri Lankan tea export share in the global market is coming down and Sri Lanka has lost many of its traditional country markets. This commodity export orientation has failed for several reasons. Tea as a commodity finds relatively low growth in demand in the global market; tea exports are 
aimed at the stagnant regions and the tea producing countries have been involved in price competition in commodity market.

Global tea beverage market is estimated to be approximately US \$ 73.13 in 2024 (Statista). While the competitiveness of the Sri Lanka's tea is declining in the global market, it is very important for Sri Lankan tea to evidently identify the reasons for declining competitiveness and how Sri Lanka can face this challenge fulfilling the demand of global market. Hence, the objective of the paper is to examine the reasons for declining competitiveness of Sri Lankan tea and find issues related to the tea industry. The second objective is to suggest strategies to uplift the industry.

\section{Review of Literature}

Tea production in Sri Lanka had steady growth up to 1970 and thereafter stagnation set in the production. The nationalization of plantations in Sri Lanka is the root cause for a steep decline in the production performance. While global tea production increased by 51 per cent during the periods of 1965 to 1977, Sri Lankan tea production declined by nine per cent. Further, decline in land areas for tea cultivation and lower labour productivity are also attributed to the decline in tea production of Sri Lanka (Economic Review, 2001).

Jayasinghe and Toyoda (2005) attempted to study about the technical efficiency of organic tea smallholdings sector in Sri Lanka. Due to the demand for organic tea, cultivation of organic tea received its importance in Sri Lanka. Researchers analyse the technical efficiency of organic tea smallholdings in the mid country wet zone of Sri Lanka. The Cobb-Douglas functional specifications are found to be an adequate representation of the cross-sectional data obtained in 2002. The study indicates that there is great potential to increase production by 55 per cent through efficient use of the present technology.

The processed tea is sent to the brokers for auctions where the price for the tea is determined. Tea is sold at auction to local exporters or overseas buyers. After this sequence of supply chain, tea reaches the final consumers. Before reaching the final consumers, the supply chain takes many routes depending on the type of tea, methods of trade, market structure and type of buyer (Kasturiratne and Poole, 2006).

Sri Lanka is using orthodox and CTC method of production representing 52 percent conventional and 48 percent is CTC (Taylor and McDowell, 1999). With the orthodox type of tea, Sri Lanka has lost its lucrative major markets such as Pakistan and the United Kingdom (Fonseka, 1997). However, tea production in Sri Lanka is declining due to many reasons. One reason was that the quality and quantity of tea production depend on management practices and policies followed by plantation companies. Management of tea estates in Sri Lanka have gone through major changes during the last three decades. The management policies adopted previously was rigid and totally inappropriate in the present context. Plantation workers were suffering from poor morale and job dissatisfaction. Further, workers were not confident and were lacking in management (Hitinayake, 2001).

An alternative strategy was recommended by Basanayake \& Guneratne (2002) for managing the situation in production of tea in Sri Lanka. With growing competition in the global tea market and increasing cost of production, increasing production efficiency is an important determinant of the future of Sri Lankan tea industry. It has been observed that full time farmers are more efficient than others. Hence, it has been suggested to make all farmers as full-time workers in the industry. This may also be difficult due to price fluctuation and unfavorable climatic condition that affect the tea industry severely. For this, implementation of guaranteed price scheme would be an appropriate strategy.

Sri Lanka has established reputation as leading producer of tea in the world. There has been increasing disagreement between performance and reputation for last few years. Therefore, the export oriented industry is under increasing threats due to a range of domestic issues and international competition. These domestic issues have seriously affected Sri Lankan tea industry's productivity and efficiency (Wickramasinghe and Cameron, 2003). Sri Lanka also take many measures to overcome the weaknesses in the productivity. Sri Lanka had to take productivity improvement measures with regard to land and labour. These measures will create an opportunity for Sri Lankan tea industry to compete on cost and this type of competition on cost is not advisable in the long run. Therefore, proper strategy is to add value to the primary commodity. It was emphasized that additional investment in value added tea production is necessary for Sri Lanka to be more competitive in the global market and to enhance competitive advantage (Ariyawardana, 2001).

Tea sector is highly labour intensive and it requires labour throughout the year. The nature of work demands the involvement of both the male and the female labourers. Studies conducted by various experts and institutes have revealed that the youth in the plantation sector are not keen to follow the footsteps of their parents in the plantation sector (Chandrabose, 2005). With regard to workforce issues, chronic absenteeism of labour force is 
major challenge for Sri Lankan tea industry. For this, measures have to be taken to raise the living, housing and working conditions for the workers (Wickramasinghe and Cameron, 2003).

Mwaura and Muku (2007) suggest that in order to improve the labour productivity, the welfare of farmers should be improved. This could be done by targeting maximization of returns from tea enterprises. Tea enterprises invest massively on the tea plantations for maximum return. This, in turn, improved the productivity and the welfare of the farmers.

Mohamed and Zoysa (2006) point out that Sri Lanka is mainly using orthodox type tea production method which involves a batch process. Hence, worker productivity plays a major role in batch processing. Due to the shortage of the labour in Sri Lanka, researches are being carried out to minimize the over dependences on workers. Although some of the factories introduced the fully automated tea processing, the system resulted in deterioration of quality of tea.

Average world tea productivity is $1517 \mathrm{Kg}$ of tea per hectare (Mamati \& Yuerong, 2004). Sri Lanka's productivity is the lowest in the global scenario (Yogaratnam, 2007). The reason for the lower yield in Sri Lanka is the poor or eroded soils and poor bushes due to a large percentage of old seedling tea (ISD, 2008). Another reason for the lower yield in Sri Lanka is that the pluckers bring in much more leaf than (three times) other tea producers such as Kenya (Luxner, 2009).

According to Modder (2001), a combination of strategies has to be implemented in the Sri Lankan tea industry for higher productivity and profitability. The combination of strategies includes replanting and infilling, profitable land use, making employment in the tea industry an attractive career option, computerization and automation of factories and foreseeing the changing requirements of the global market place.

Despite the increasing cost of production, tea price at auction is not increasing considerably. The reason for this trend is the over supply of tea in the global market. Over the last ten years, price of tea has not increased substantially in the market because of this consistent surplus of tea supply into the global market which caused depression on the auction prices (Gesimba, et al., 2005). The reason for the increase in the global supply of tea is the greater emphasis given to improvement of productivity and output expansion in all tea producing countries including Sri Lanka (Perera \& Bernard, 1995). Further, the orthodox method of production incurs more cost than the CTC method (Komancheck, 2009).

There are two factors causing the vulnerability for farmers. The first is the corporate concentration in the global tea supply chain. This means that a small number of companies dominate the tea industry. This creates funnel effect in the supply chain. This, in turn, leads to concentration of power with buyers compared to producers. Due to this funnel effect, there is wider marketing margin between value added tea export prices and average price at tea auctions. Thus, tea growers are not fully getting the benefits from the growing demand for value added tea products (Fairtrade Foundation, 2010).

Sri Lankan tea is formally known as the best tea in the world. This image seems to be vanishing among the consumers in the international market due to various issues related to the tea products. Sri Lanka is exporting orthodox type of tea to the world markets. Due to the uniqueness of this type of tea, its name and image was always among the consumers. This image is now being deteriorated. Hence, the export oriented industry is under increasing threat from within and without because of lower productivity and efficiency while increasing international competition which affects product price and profitability (Wickramasinghe and Cameron, 2003).

Since the international tea market is very competitive Sri Lanka is facing rigorous competition in the international market (Yuliando and Akira, 2006). The competition is at two levels. First level is among the tea producing countries. Kenya and other new comers are producing tea at low cost of production than Sri Lankan tea. This leads to competition on price. The second level of competition is between local firms and foreign firms. Sri Lanka is unable to compete in the international market. Imperial, Akbar, Dilmah and Mlesna are competing with multinational companies such as Unilever and Tata Global Beverages. These multinational companies have huge resources for both manufacturing and marketing. This is one of the major external constraints for Sri Lankan companies (Sri Lanka Government, 1995). Further, these multinationals and private brand owners create sufficient competitive environment for the development of the value added tea industry in Sri Lanka (Ganewatta, 2005).

\section{Methodology}

The study is based on secondary data and primary data. The study comprised of two stages in the research process. At the first stage, secondary data were obtained from research studies, reports of international organisations, articles in research journals, etc. The stage involved analysis of the secondary data as well. At the 
second stage primary data were collected through a qualitative study. The qualitative method used was expert opinion survey. The expert opinion survey was conducted among tea industry experts in Sri Lanka and India. The qualitative study was used to vet some of the information obtained from the analysis of the secondary data. The primary data collected were through a semi structured interview, using a check list of questions.

Expert opinion survey means that getting opinion from people who spend more time on particular subjects and who have gathered much general information that has been filtered through their minds and stored in their memories (Simon, 2009). The qualitative research method used here is expert opinion survey. As far as this study is concerned, other method such as interviews, focus groups, observation and deductive reasoning are not appropriate, due to the limitations in collecting primary data about the country markets. Expert opinion survey is most suited for studies when there are difficulties to collect data by other techniques (Cresswell, 2007).

The expert opinion survey was conducted among 53 tea industry experts. The respondents included executives of tea exporting companies, managers of companies producing tea and tea products and executives of Tea Boards. Two samples of respondents were drawn: one from Sri Lanka and the other from India. In Sri Lanka 29 respondents were drawn from 19 tea companies and Sri Lanka Tea Board. In India 24 respondents were drawn from 20 tea producing and exporting companies and the Tea Board India.

In order to collect the primary data, a check list of questions was prepared after preliminary discussions with a few tea industry experts. Semi-structured interviews were held with the respondents. The responses to the questions were recorded in paper. On an average one hour was spent for each interview.

The responses were analysed to obtain relevant information pertaining to different issues under study. Information and opinions of different respondents were cross checked while analysing the qualitative data.

\subsection{Major Issues in the Sri Lankan Tea Industry}

Sri Lanka is exporting 90 per cent of the tea to the world market and only 10 per cent is locally consumed. The industry is entirely dependent on the international market for survival and declining competitiveness is a serious issue that needs to be addressed strategically.

The price of Sri Lankan tea in the global market is very high, compared to the tea produced by other tea producing nations. The reason for this price increase is the high cost of production in Sri Lanka. The highest cost of production in the world is for Sri Lankan tea. Table 1gives the cost of production per kilogram of tea for various major producing nations.

Table 1. Cost of production for Sri Lanka's tea

\begin{tabular}{rcc}
\cline { 2 - 2 } \multicolumn{1}{l}{ Year } & Cost of Production (Cost / Kg) \\
\cline { 2 - 3 } $2006 / 07$ & 210.75 \\
$2007 / 08$ & 231.48 \\
$2008 / 09$ & 269.01 \\
$2014 / 15$ & 478.23 \\
$2015 / 16$ & 458.84 \\
$2016 / 17$ & 466.98 \\
Source: Department of Census and Statistics & 475.29 \\
\hline
\end{tabular}

The cost of production per $\mathrm{kg}$ was SLRs 210.75 in the year 2006/07 and this increased to SLRs 475.29 in 2017/18. This is a more than 125 per cent increase. This is the prime reason for the continuous increase in the price of Sri Lankan tea when compared to the other tea producing countries.

In the case of tea production, Sri Lanka's production of tea is almost stagnant. Production of tea is given in Table 2. 
Table 2. Tea production of major producing countries (000’ MT)

\begin{tabular}{lcccccccccc}
\hline Major Producers & $\mathbf{2 0 0 9}$ & $\mathbf{2 0 1 0}$ & $\mathbf{2 0 1 1}$ & $\mathbf{2 0 1 2}$ & $\mathbf{2 0 1 3}$ & $\mathbf{2 0 1 4}$ & $\mathbf{2 0 1 5}$ & $\mathbf{2 0 1 6}$ & $\mathbf{2 0 1 7}$ & $\mathbf{2 0 1 8}$ \\
\hline China & 1310.0 & 1370.0 & 1550.0 & 1915.0 & 1850.0 & 1980.0 & 2230.0 & 2350.0 & 2550.0 & 2616.0 \\
Sri Lanka & 289.8 & 329.4 & 328.4 & 326.3 & 340.2 & 338.0 & 328.9 & 292.4 & 307.1 & 303.8 \\
India & 978.9 & 966.4 & 988.3 & 1111.8 & 1200.0 & 1184.0 & 1191.0 & 1239.2 & 1278.8 & 1311.4 \\
Kenya & 314.2 & 399.0 & 377.9 & 369.5 & 432.4 & 445.1 & 399.2 & 474.8 & 439.8 & 492.9 \\
Indonesia & 136.5 & 129.2 & 123.7 & 130.5 & 134.0 & 132.0 & 129.3 & 125.5 & 124.5 & 131.0 \\
\hline
\end{tabular}

Source: FAO Statistics

Figures given in Table 2 are depicted in a line graph.

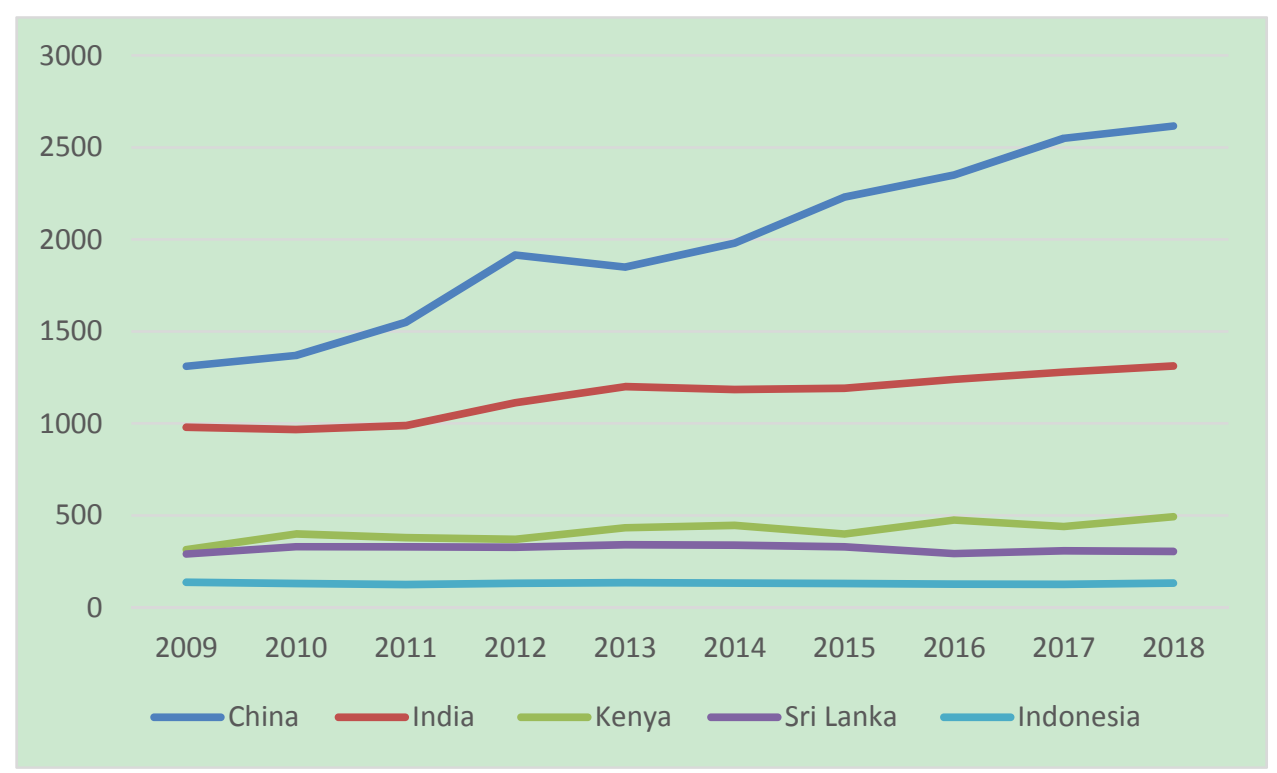

Figure 1. Tea production of major producing countries

The largest tea producer of tea in the world is China with the production of 2616 thousand metric tones of tea in 2018. China's tea plantations occupy 1.86 million hectares or approximately half of the world's total surface area under tea. Data in Table 2 show that tea production in China has been growing rapidly. India was the largest tea producer in the world in 2005 and it has become second largest producer of tea in the world. The third largest tea producer is now Kenya with the production of 492.9 thousand metric tone of tea in 2018. While the tea production is increasing in major producing countries such as China, India and Kenya, Sri Lanka is ranked at the fourth place in the production. Further, it has also been evidently observed that the production of tea has been stagnant in Sri Lanka.

It is also important to analyze the tea exports from Sri Lank. The exports of different categories such as tea bags, bulk tea and packeted tea are given in Table 3.

Table 3. Categorywise exports (000' Kgs)

\begin{tabular}{lcrrrrrr}
\hline Category & $\mathbf{2 0 1 2}$ & $\mathbf{2 0 1 3}$ & $\mathbf{2 0 1 4}$ & $\mathbf{2 0 1 5}$ & \multicolumn{1}{c}{$\mathbf{2 0 1 6}$} & \multicolumn{1}{c}{$\mathbf{2 0 1 7}$} & \multicolumn{1}{c}{$\mathbf{2 0 1 8}$} \\
\hline Tea bags & 25813.5 & 27740.0 & 30710.9 & 23978.9 & 24816.5 & 18523.8 & 23411.9 \\
Bulk tea & 132527.1 & 130817.2 & 128304.1 & 133868.8 & 126288.4 & 124340.4 & 123543.6 \\
Packets tea & 161606.0 & 161103.6 & 168327.3 & 149088.7 & 137665.7 & 135330.9 & 135407.9 \\
\hline
\end{tabular}

Source: Sri Lanka Tea Board

Sri Lanka's different categories of tea exports are depicted in Figure 2 below. 


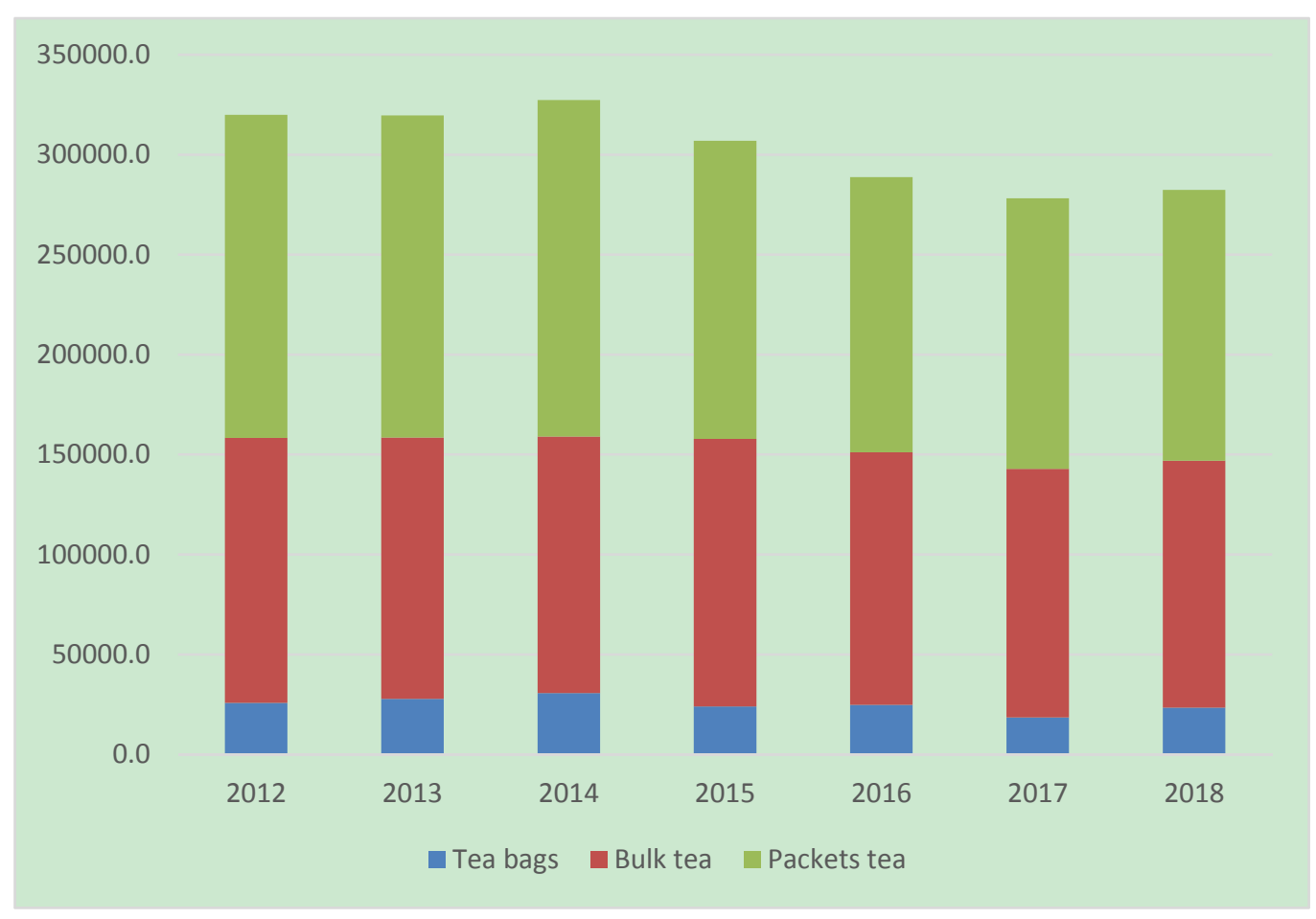

Figure 2. Exports of different categories of tea (Kgs.)

Figure 2 explains the exports of tea of different categories. Consumption of tea of value-added tea is increasing in the global market. However, Sri Lanka's exports of value-added tea is stagnant or declining. Interview with exporters revealed that consumer preferences have been changing in the international tea markets. In the world now consumers want tea bags and instant tea. The traditional tea brew is likely to be obsolete. The young generations prefer to tea products which is convenient to fulfill the requirements of tea. Some consumers want and some are expecting benefits of health from tea. The reason for Sri Lanka's catastrophe in some major markets is that it is unable to respond to the changing consumer preferences and demand. Consumers in the developed world are more sophisticated in their product choice and taste. Hence, products have to be developed to match the sophistication of the markets. Sri Lankan value added tea products exports are almost stagnant for the last several years. The reason for the stagnation in exports of value added tea products is the current focus on orthodox type of tea production. With the increasing consumption of teabag in the global market, Sri Lanka attempted to expand the CTC variety of tea production, but it did not succeed. Since Sri Lanka is unable to meet the requirements of global consumers, its global export share has been coming down in the international tea market.

There are other factors which also affect the competitiveness of Sri Lankan tea. Labour productivity has influenced the tea yield in Sri Lanka (RAM, 2010). The factors are chronic absenteeism and lack of workforce continuity. People in plantations have aspiration for greater living standards with recognition of the society and hence they encourage their family members to seek employment elsewhere.

Discussions with experts divulge that the major problem of the industry is sky rocketing cost of production. The reason for the increasing cost of production is increasing labour wages, increase in fuel prices and increase in charges of electricity and fertilizers.

Climatic conditions pose another problem. The climate in the areas of tea plantation is adversely affecting the production of tea. Under unfavorable climatic condition, the tea plantation companies receive crops lower than during the climatic condition favorable. Climatic conditions are not predictable as in the past. Sudden changes in the climate adversely affect the crops. The quality of tea is also badly affected.

Another problem is that the bushes are very old. Sri Lankan tea plantations are getting low yield and low-quality output. Around 50 per cent tea plantation are with the age of more than 100 years. and hence rendered less productive. Political interference through trade union actions also has negative impact on the tea production. 
In the case of production and quality factors, Sri Lanka is the number one orthodox tea producer in the world. In addition, tea in Sri Lanka is being produced at different elevation with different condition of climate in Sri Lanka The best tea is with golden liquor and strong flavor. This is also called as high grown tea. Another type is with good flavor, good aroma and colour which is called as medium grown tea. Leafy grade tea is low grown tea which is another type produced in Sri Lanka. This is used by consumers for normal use in blending. Thus, quality also differs according to the types of tea such as high, lower and medium grown tea. These different types of tea are used for enjoying competitive advantage in the global market place.

Analysis reveals that the competitiveness of Sri Lankan tea is declining and therefore, there may be an issue in terms of achieving economic objectives and it may negatively impact the tea business and plantations.

\subsection{Discussion on Sri Lankan Bulk Tea Export and Changing Global Consumption}

Sri Lankan tea industry is mostly focusing on bulk tea exports all over the world. However, various transformations have taken place in the global market such as changing consumption patterns, high cost of production, development of value added tea products, etc. Due to this transformation, most of the export destinations face changes in markets and Sri Lanka is still losing the pioneering and first mover advantages (Kasturiratne, 2008). Further, Sri Lanka is unable to generate profits in the tea exports since Sri Lanka is focusing on bulk tea exports, though value added forms of tea enjoy 250 per cent price premiums compared to bulk tea (RAM, 2010).

Sri Lankan tea is expensive in the world as Sri Lanka is with the highest cost of production. Other producers (Vietnam, Indonesia and Kenya) in the world offer tea at lower prices in the international market. Further, Sri Lankan tea is also affected by production and quality factors, tariff charges, local blending and processing of tea in the consuming countries.

The market needs more of tea bags for quick cup of tea, instant tea to match instant coffee and flavoured tea and iced tea to match carbonated drinks (Fonseka, 1997).

In the global tea market, value-added tea has captured an extensive position because of the sophistication of tea consumption patterns. As a result, the future demand for tea is likely to be different from that of the past, and there could be more demand for convenience-oriented products. Consumer preference for loose tea is on the decline, while demand for tea bags and ready-to-drink tea is on the increase (Ariyawardana et al, 2001).

In addition, markets in Middle East and in Pakistan are made up of packet tea and majority of western and North American countries are for tea bag. Experts explain that changing consumer preferences, particularly among the younger generation favour specialty tea such as green tea, white tea, etc. value added tea has higher demand comparatively in the major markets. For instance, demand for tea bag is facing rapid growth in most of the cities in the world. People in some countries need organic tea which has more health benefits (Ariyawardana et al, 2001). This trend shows that there is growing demand for innovative and value added tea products in the international market.

Since organic and value added tea face greater demand all over the world, Sri Lankan tea industry can do value addition at the primary production itself. That implies converting traditional tea production into organic tea. Sri Lankan tea depends mostly on CIS, Russian Federation and Middle Eastern countries' markets. About 70 per cent of the bulk tea is exported to these markets (Ranaweera, 2007). This could be risky for Sri Lankan tea industry as these markets are huge for bulk tea. Competitiveness of Sri Lankan tea is coming down in the global market owing to the high cost of production. These markets may get cheaper tea from the other origins. Hence, rather than depending on these markets, Sri Lanka can target sophisticated customers in developed countries such as the European Union where there is good demand for value added tea products.

An advantage of Sri Lanka is that it produces different verities of tea, which belong to different regions, and are preferred by different global consumers. High grown tea is reputed for the taste and aroma. This tea is much sought by blenders in the importing countries. Uva tea from Eastern Highlands is unique in characters and it is widely used in Germany and Japan. The medium grown tea, which offers thick colour variety, is popular in Australia, Europe, Japan and North America. The tea produced in low grown areas is prominent in Western Asia, Middle Eastern countries and CIS. These teas are leafy grade teas (ISD, 2008). These varieties offer opportunities for segmentation and target marketing strategies.

Sri Lankan tea industry is not looking at what the competitors are doing in the international market. They observe only difference in exports of tea of the present and the past and they do not think strategically to compete in the global tea/ beverage market. Further, the firms in the industry are not examining the strategies and revising them over time (Kasturiratne, 2008). Sri Lanka is exporting 90 per cent of the tea to the world. In 
fact Sri Lanka is entirely depending on the international market for survival. Declining competitiveness is a serious issue that needs to be addressed strategically in terms of satisfying consumer requirements better than competitors. For this, it is necessary to increase the value added tea production in Sri Lanka so as to compete in the international tea market and to sustain the competitive advantage.

\section{Conclusion and Recommendations}

Major portion of Sri Lankan tea is exported in the form of bulk tea to well-known packers and blenders in the world for value addition. Only nominal returns are realized by the tea growing country, while large margins accrue to firms engaged in forward processing. This concentration provides opportunity for the blenders to exert market power.

Despite the fact that Sri Lanka is one of the major producers of tea, the local tea industry does not earn enough to be viable. It has been pointed out that the blender's margin is about 24-28 per cent, the distributor's margin is about 15 per cent and the packer earns about 22-37 per cent. Global consumers are paying more than ten times the price received by the Sri Lankan producers. The economic benefits of high prices for value addition in the tea industry does not reach tea producing country. Instead, the economic benefits go to the consuming countries where the value addition is done. In this context the viability of the Sri Lankan tea industry makes it imperative to adopt production of value added tea products, promoting local brands in the global market and marketing the products in the international market.

Tea export from Sri Lanka has been declining primarily on account of the changing consumption pattern of tea in the international market. In most developed countries, consumer preferences shift towards convenient and instant tea products. As a result, convenient tea products such instant tea, tea bags, RTD tea and organic tea are replacing bulk tea in international market.

Most of the Sri Lankan companies are just exporting tea to major markets for either consumption or local blending and branding. Since they are exporting bulk tea to the major consuming nations where tea products are replacing bulk tea, Sri Lanka is facing a decline in the exports of tea.

Sri Lankan tea industry is losing its market leadership in the international market since the industry continues to be production oriented without considering the market needs. Although few local companies in Sri Lanka get involved in international marketing, by and large Sri Lankan tea companies are just exporting tea to foreign markets. Even when Sri Lankan companies export value added tea to the world, they do not engage in international marketing activities seriously.

Along with establishing special economic zones, Sri Lankan government may allow import of tea (CTC) from other nations to produce value added tea products in Sri Lanka. Local companies and investment will also be attracted to the zone. By producing tea products, Sri Lanka could become the production centre for tea products and transform itself into a tea trade hub in the world.

Production of value added tea products need considerable investment and foreign investment will be a major boost for the industry. Sri Lanka can allow foreign companies to start value addition domestically or Sri Lankan companies can have joint ventures with foreign companies for value addition. In course of time, Sri Lankan companies can start their manufacturing and international marketing of value added tea products globally. By doing so, these local companies will improve their skills and activities in relation to the international marketing. Sri Lankan government should encourage foreign companies to set up tea products processing plants in Sri Lanka.

A major reason for low production of value added tea products in Sri Lanka is lack of technology. Government can encourage import of technology and machinery for value addition in the tea sector.

In Sri Lanka most of the companies are lacking in resources in relation to marketing and operations. In order to overcome this problem, global strategic partnership can be established between Sri Lankan companies and foreign companies. These partnerships and strategic alliances may open up possibilities for many firms to expand globally.

Sri Lankan Tea Board should provide assistance, including financial assistance, to promote Sri Lankan tea brands in the international market. The priority in such assistance should be for local companies.

Many Sri Lankan companies lack proper market information pertaining to consumer preferences and competitive environment pertaining to the tea market. Government sponsored detailed market studies are required in prospective country markets to identify preferences for different types of tea bags, instant tea and green tea blends, in addition to other aspects of market studies 
The Sri Lankan Tea Board can take the initiative to conduct detailed market research studies for international marketing of Sri Lankan tea.

The Sri Lankan Tea Board can develop and R\&D division for tea product innovations and also take initiative to encourage R\&D for tea product development among tea processing companies.

Government can provide assistance to set up more companies to market Sri Lankan tea products in the international market. There are several new companies entering into value added tea products. Many traditional packers are now offerings herbal blends as well as specialty tea blends. Many bottled water and soft drink companies have expanded their product lines to ready to drink tea. Marketing companies established for international marketing of Sri Lankan tea can directly supply to leading supermarkets chains.

The tariffs should be brought down by the importing countries. Sri Lankan tea products are being levied high duty in many markets. Consequently, Sri Lanka is unable to exports its value-added tea products to those markets. World Trade Organization could be the appropriate forum for negotiations. Tariffs reduction has been done by several countries for Kenyan tea. Since there is major tea producing countries in the SAARC region, this body can also be involved in activities to negotiate tariff reduction on tea products.

Many tea plantation workers are leaving the industry to take up jobs elsewhere. Young people are not joining the industry. There is a shortage of work force in the tea sector. Therefore, the government can take steps to retain the workers and provide them with incentives to work in the plantation. For this Sri Lankan government can adopt a policy of promotion from within. Tea estates and plantation may devise a system in which a field worker can move up to an educator or health aid or administrator. Other relevant schemes can also be devised.

The market for organic foods and beverages is increasing in the countries in Western Europe, North America, Japan and Australia. Organic tea has growing demand in the international market. The market for organic tea is growing all over the European countries, North America and Australia. Sri Lanka has succeeding in establishing organic tea farming. An organic tea garden is situated in UVA Highlands in Sri Lanka. Presently, Sri Lanka is exporting organic tea to Europe, Australia and Japan. There may be insufficient supply of organic tea in future due to the growing demand. Therefore, it is better for Sri Lankan tea industry to increase the organic tea production. The government should evolve policies to encourage organic tea farming in the country.

Tea which contains pesticide residues is rejected by European Union countries. Most countries are specifying maximum residue limit for tea. This is reducing demand for Sri Lankan tea in the global market. Testing facilities for pesticide residues should widely be set up in Sri Lanka.

One of the major reasons for loss in tea plantations is the low yield from aged plants, degraded soils and under implementation of good agricultural practices. This is leading to the decline in the productivity. The worse scenario is that the estates will be compelled to curtail or totally abandon the development programmes such as replanting or new planting, factory modernization and social welfare activities. This is one of major problems in Sri Lankan tea industry. The government should take efforts to regularize good agricultural practices and encourage new and replanting to increase the production.

In Sri Lanka, area planted with tea has not been increasing significantly. For the last few years new planting has also not been taken place in Sri Lanka. Many plantations are very old. The government should provide adequate financial support through grant and loan for new planting and replanting to increase the tea production.

Further, some of the varieties developed in Sri Lanka by the Tea Research Institute had been yielding more than $8000 \mathrm{~kg} / \mathrm{ha}$ in South Indian under commercial conditions. The Sri Lankan Tea Board should provide agricultural extension support and financial assistance to promote the new varieties of tea.

\section{References}

Ariyawardana, A., \& Bailey, W. C. (2002). The Relationship between Core Resources and Strategies of Firms: The Case of Sri Lankan Value Added Tea Producers. Sri Lankan Journal of Agricultural Economics, 4(1), 1-18. https://doi.org/10.4038/sjae.v4i0.3481

Ariyawardana, A., Nithiyanandam, V. N., \& Bailey, W. C. (2001). Globalization Challenges for Tea Producing Countries: The Case of Sri Lanka, Paper presented at the 8th International Conference on Sri Lankan Studies, University of Rajasthan, Jaipur, India.

Basnayake, B. M. J. K., \& Guneratne, L. H. P. (2002). Estimation of Technical Efficiency and Its Determinants in the Tea Small Holding Sector in the Mid Country Wet Zone of Sri Lanka. Sri Lankan Journal of Agricultural Economics, 4(1), 137-150. https://doi.org/10.4038/sjae.v4i0.3488 
Chandrabose, A. S. (2005). Labour Turnout in the Plantation Sector: A Study on Selected Large Scale Tea Estates in Sri Lanka, Proceedings of the $10^{\text {th }}$ International Conference on Sri Lanka Studies, December 16-18, University of Kelaniya, Sri Lanka, p. 90.

Creswell, J. W. (2007). Qualitative Inquiry and Design: Choosing Among Five Traditions, 2nd.

Economic Review. (2001). Progress of the Tea Industry - Sri Lanka's Experience, July/August, pp. 2-5.

Fair Trade Foundation. (2010). String Up the Tea Trade: Can be a Better Future for the Tea Producers? Fair Trade Briefing Paper, February.

Fonseka, A. T. (1997). Strategic Approach to Marketing of Sri Lankan Tea, Sri Lankan. Journal of Management, 2(2), 155-183.

Fonseka, A. T. (1997). Strategic Approach to Marketing of Sri Lankan Tea. Sri Lankan Journal of Management, 2(2), 155-183.

Ganewatta, G., Waschick, R., Jayasuiya, S., \& Edwards, G. (2005). Moving up the Processing Ladder in Primary Product Exports: Sri Lanka's Value Added Tea Industry. Agricultural Economics, 33, 341-350. https://doi.org/10.1111/j.1574-0864.2005.00073.x

Gesimba, R. M., Langat, M. C., Liu, G., \& Wolukau, J. N. (2005). The Tea Industry in Kenya: The Challenges and Positive Developments. Journal of Applied Sciences, 5(2), 334-336. https://doi.org/10.3923/jas.2005.334.336

Hitinayake, G. (2001, July/August). Changes Introduced in the Management System in the Tea Plantation - Net Impact \& Important Issues. Economic Review, 26-29.

Institute of Social Development (ISD), Report on Sri Lankan Tea Industry.

Jayasinghe, J. M. J. K., \& Toyoda, T. (2004). Technical Efficiency of Organic Tea Smallholding Sector in Sri Lanka. International Journal of Agricultural Resources, Governance and Ecology, 3(3), 252-265. https://doi.org/10.1504/IJARGE.2004.006039

Kasturiratne, D. (2008). An Overview of the Sri Lankan Tea Industry: An Exploratory Case Study. The Marketing Review, 8(4), 367-381. https://doi.org/10.1362/146934708X378659

Kasturiratne, D., \& Poole, N. (2006). Creating value for competitive advantage in supply chain relationships: the case of the Sri Lankan tea industry. In: The 99th EAAE Seminar 'Trust and Risk in Business Networks', 8-10 February, Bonn, Germany.

Komancheck, W. (2009). From the Field to the Cup. Tea \& Coffee Trade Journal, 181(11), 36-43.

Luxner, L. (2009). In Sri Lanka, Tourism With A Capital “Tea”. Tea \& Coffee Trade Journal, 181(7), 28-31.

Mamati, G. E., \& Yoerong, L. (2004). Tea (Camellia Sinensis): Comparison of the Crop in Kenya and China. Journal of Tea, 30(4), 197-202.

Modder, W. W. D. (2001, July/August), Success and Trends in Tea Research. Economic Review, 13-16.

Mohamed, M. T. Z., \& Zoysa, A. K. N. (2006). Current Status And Future Research Focus of Tea In Sri Lanka. Journal of Agricultural Science, 2(2), 32-42. https://doi.org/10.4038/jas.v2i2.8129

Mwaura, F., \& Muku, O. (2007). Tea Farming Enterprise Contribution to Smallholders' Well Being In Kenya, AAAE Conference Proceeding, pp. 307-313.

Perara, G., \& Bernard, K. (1995). Export potential of Tea. Economic Review, 21(6), 23-27.

RAM Rating. (2010). Sector Report: The Green Gold of Ceylon.

Ranaweera, S. (2007). Future of Sri Lankan Tea is in Value Addition, Sunday Times, 23 December.

Simon, J. L. (2009). The Art of Empirical Investigation (2nd Ed.). Transaction Publisher, United States of America.

Sri Lanka Government. (1995). Report on the Presidential Commission on the Tea Industry and Trade: Paper No. II, Government Publicaiton Bureau, Colombo, Sri Lanka.

Taylor, S., \& McDowell, I. (1999). Tea. Types, Production and Trade. Encyclopedia of Food Sciences and Nutrition, pp. 4521-4527.

Wickramasinghe, D. W. A., \& Cameron, D. (2004). A Cultural Political Economy of Business Strategy in a Developing Country Context - The Case of the Sri Lankan Tea Industry, Paper presented at University of 
Cambridge, Journal of Radical Organizational Theory: Abstracts of the 4th International Critical Management Studies Conference, pp. 323

Yuliando, H., \& Akira, N. (2006). Supply Management Options for Tea Producing Countries: A Case Study on Indonesian Tea Product and Its Competitors. Journal of Applied Sciences, 6(15), 3170-3173. https://doi.org/10.3923/jas.2006.3170.3173

\section{Copyrights}

Copyright for this article is retained by the author(s), with first publication rights granted to the journal.

This is an open-access article distributed under the terms and conditions of the Creative Commons Attribution license (http://creativecommons.org/licenses/by/4.0/). 